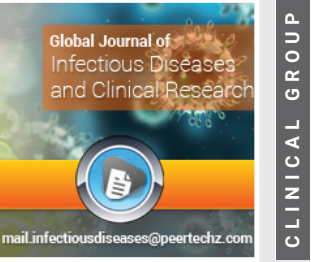

\section{Safety of convalescent plasma to treat COVID-19: Systematic} review

\section{Ephrem Awulachew*, Kuma Diriba, Asrat Anja and Firehiwot Belayneh}

Department of Medical Laboratory Science, College of Health Science and Medicine, Dilla University, Ethiopia
Received: 16 April, 2020

Accepted: 27 June, 2020

Published: 29 June, 2020

*Corresponding author: Ephrem Awulachew, Department of Medical Laboratory Science, College of Health Science and Medicine, Dilla University, Ethiopia, Tel: +25149181161; E-mail: efriye@gmail.com

Keywords: COVID-19; Convalescent plasma; Plasma; SARS CoV 2; Severe acute respiratory syndrome

https://www.peertechz.com

\section{Check for updates}

\begin{abstract}
Background: Currently, Coronavirus disease (COVID-19) was reported in more than 204 countries. As of April 10, 2020, a total of 1,605,729 confirmed cases and 95,766 deaths had been reported worldwide. There are no approved specific antiviral agents targeting the novel virus. Convalescent plasma transfusion might be effective against the infection. Food and Drug Administration (FDA) has also approved the emergency use of investigational COVID-19 convalescent plasma to treat severely ill COVID-19 patients.
\end{abstract}

Objective: The aim of this study was to systematically review disease outcome and safety of convalescent plasma to treat COVID-19.

Method: We searched literature published in English from December 20 /2019 to April 10/2020 on electronic databases. Using R software we have conducted a systematic analysis, frequency, mean, standard deviation, and chi-square test.

Result: The average age of the participants in the included was 55.7 with a standard deviation of 13.9. The average days of recovery or test negative for the COVID-19 PCR test after convalescent plasma therapy were 9.6 days ( $95 \% \mathrm{Cl} 2-30$ days). About $43 \%$ (9/21) had a history of comorbidity. The average date of recovery of patients with co-existing chronic diseases infected by COVID-19 after convalescent plasma therapy was about 12 days relatively prolonged than patients without the co-existing disease (7.6 days). No series adverse effects have been demonstrated in patients who have received convalescent plasma transfusion.

Conclusions: This study indicated that convalescent plasma transfusion might be a potential treatment for critically ill patients with COVID-19 pneumonia. It could be helpful to reduce the risk of mortality of critically ill patients. We demonstrated no serious adverse reactions associated with the transfusion of convalescent plasma.

\section{Background}

The Severe Acute Respiratory Syndrome coronavirus 2 (SARS-CoV-2) is a novel strain of coronavirus that was first detected in the city of Wuhan, China $[1,2]$. It was named as coronavirus disease 2019 (COVID-19) by World Health Organization (WHO) [3,4]. The outbreak SARS-CoV-2 was named as a pandemic disease by WHO on March 11, 2020. Currently, the disease was reported in more than 204 countries. As of April 10, 2020, a total of 1,605,729 confirmed cases and 95,766 deaths had been reported worldwide [5]. Currently, due to an alarmingly spreading of the virus worldwide, the incidence and deaths are increasing. However several efforts made to treat COVID-19, there are no approved specific antiviral agents targeting the novel virus, and no vaccines have been fully tested for safety and efficacy while some drugs are still under investigation.

Convalescent Plasma (CP) therapy is an immunotherapy that has been applied to the prevention and treatment of many infectious diseases for more than one century. So, the use of convalescent plasma is not a new method rather it was used for poliomyelitis [6], measles [7], mumps [8], and influenza [9], Severe Acute Respiratory Syndrome (SARS), several hemorrhagic fevers such as Ebola, and other viral infections treatments [10]. Even more recently during H1N1 influenza virus pandemics in 2009-2010, convalescent serum antibody preparations obtained by apheresis were used to treat individuals with severe $\mathrm{H} 1 \mathrm{~N} 1$ infection requiring intensive care [11]. This was the baseline lesson for convalescent plasma to treat COVID-19. 
Plasma from people who have recovered from COVID-19 may contain antibodies to the virus that causes the disease and might be effective against the infection [12]. Food and Drug Administration (FDA) has also approved the emergency use of investigational COVID-19 convalescent plasma to treat severely ill COVID-19 patients [12]. The general principle of passive antibody therapy is that it is more effective when used for prophylaxis than for treatment of disease [13]. When used for therapy, the antibody is most effective when administered shortly after the onset of symptoms [14]. So it is required to evaluate the effectiveness of convalescent plasma therapy. So this study planned to conduct systematic analysis of literatures on Convalescent plasma treatment in severely ill COVID-19 patients.

\section{Objective}

The main aim of this study is to systematically review the safety of convalescent plasma to treat COVID-19.

\section{Materials and methods}

\section{Types of participants}

The study population of interest was human subjects of any age or sexes who were hospitalized or were in ICU with COVID-19 infection. The intervention of interest was convalescent plasma transfusion. Outcomes of disease progress after Convalescent therapy that was extracted from included studies was used predict the clinical effectiveness of therapy.

\section{Search strategy}

We searched literatures published in English from December 20 /2019 to April 10/2020 on electronic data bases PubMed, Cochrane library, EMBASE, Escopus, Hinari, CINAHL, Open Access Journals (OAJ) and Google scholar, for studies conducted trial of convalescent plasma treatment of COVID-19. We simultaneously searched reference lists of all recovered articles for potentially eligible studies. All identified keywords, and mesh terms were combined using the "OR" operator and "AND" operator for searching literatures. Keywords used in the search included were those that explain infection of severe acute respiratory syndrome 2 (SARS CoV 2) (i.e., COVID-19, severe acute respiratory syndrome 2 , SARS $\mathrm{CoV} 2$, novel corona virus). Full-text articles were retrieved after review of the title and abstract.

\section{Inclusion and exclusion criteria}

Inclusion criteria: All studies published in English from December 20 /2019 to April 10/2020 were included in the review. There was no restriction to study design made.

\section{Data extraction}

Data were extracted from included study by two investigator (EA, and $\mathrm{KD}$ ) using a standardized data extraction form. Then the extracted data were merged together for systematic analysis. Primary outcomes extracted from each study were, the citation details, sample size, number of cases, year of publication, location of study, method of identification of COVID-19. Secondary outcomes for this study included clinical data including the stage of disease, treatment received, co-morbidities, co-infection, and dates of recovery after convalescent plasma transfusion, progress opacities in the lung.

\section{Statistical analysis}

The $\mathrm{R}$ software was used to conduct systematic analysis, frequency, mean, standard deviation, and chi-square test.

\section{Results}

\section{Identified studies}

Following the initial search of data bases four eligible studies have been accessed and were reviewed by the authors. Following methodological quality assessment, all 4 articles were eligible [15-18] and included in this systematic review and meta-analysis. In the included studies the total of 21 patients infected with COVID-19 were obtained convalescent plasma therapy. All 4 papers were published in English.

\section{Characteristics of included study}

Of the 4 studies included in the Systematic review and Meta-analysis, all studies reported the detail case report of COVID-19 patients. All patients were severely ill and were put to Intensive Care Unit (ICU) (Table 1). All 4 studies included in the systematic review and Meta-analysis, infections of COVID-19 were examined using PCR which is of high quality diagnostic method. Most of the studies conducted are of higher quality because of method of diagnosis using highly sensitive and specific PCR techniques.

\section{Systematic analysis outcome}

The average age of the participants in the included was 55.7 with standard deviation of 13.9. From a total of 21 patients 12 of them were male. The average days between admissions to start of convalescent plasma therapy was $10 \pm 4.5$ days and the average days of recovery or test negative for CIVID-19 PCR test after convalescent plasma therapy was 9.6 days (95\% CI 2 - 30 days). About $43 \%(9 / 21)$ had history of comorbidity and about $24 \%(5 / 21)$ have co-infections, while $19 \%(4 / 21)$ patients are have both history of co-existing disease and co-infections (Figure 1).

\section{Common sign and symptoms and complications of in patients of COVID-19}

In this systematic review the most common symptoms at disease onset were fever, cough with clear sputum, and shortness of breath, while less commonly observed sign and symptoms were; chest pain, sore throat, myalgia and arthralgia (Figure 2). Majority of complications observed in the study participants were severe acute respiratory distress $(85.7 \%)$, pneumorrhagia, cystorrhagia and gastrointestinal bleeding, myocardial damage, and cardiac dysfunction.

\section{Co-morbidity, co-infection and rate recovery of patients with COVID-19 after treatment by CP}

According to data of systematic review and meta-analysis 
Table 1: Characteristics of patients in the included study.

\begin{tabular}{|c|c|c|c|c|c|c|c|c|}
\hline Author & Age & $\operatorname{sex}$ & CPT & History of comorbidity & co-infection & $\begin{array}{l}\text { days from } \\
\text { CPT to } \\
\text { negative } \\
\text { viral test }\end{array}$ & Treatment received & Complication \\
\hline patient 1 & 69 & $\mathrm{~F}$ & $900 \mathrm{ml}$ & hypertension & Bacteria and fungi & 21 & $\begin{array}{l}\text { arbodol, lopinavir-ritonavir, interferon } \\
\text { alpha inhalation }\end{array}$ & bloody sputum \\
\hline patient 2 & 55 & M & $200 \mathrm{ml}$ & None & None & 8 & $\begin{array}{c}\text { arbidol, lopinavir-ritonavir, interferon alfa, } \\
\text { methylprednisolone }\end{array}$ & \\
\hline patient 3 & 73 & M & $2400 \mathrm{ml}$ & $\begin{array}{l}\text { hypertension \& chronic } \\
\text { renal failure }\end{array}$ & aspergillus infection & 30 & $\begin{array}{c}\text { arbidol, lopinavir-ritonavir, interferon alfa, } \\
\text { oseltamivir, ribavirin }\end{array}$ & $\begin{array}{l}\text { pneumorrhagia, cystorrhagia } \\
\text { and gastrointestinal bleeding }\end{array}$ \\
\hline patient 4 & 31 & $\mathrm{~F}$ & $300 \mathrm{ml}$ & pregnancy & $\begin{array}{c}\text { Gram-positive } \\
\text { bacteria bacteremia }\end{array}$ & 16 & lopinavir-ritonavir, ribavirin, & Cardial dysfunction \\
\hline patient 5 & 70 & M & $400 \mathrm{ml}$ & None & Bacterial pneumonia & 14 & $\begin{array}{l}\text { Lopinavir-ritonavir; interferon alfa; } \\
\text { favipiravir, Methylprednisolone }\end{array}$ & Severe ARDS; MODS \\
\hline patient 6 & 60 & M & $400 \mathrm{ml}$ & $\begin{array}{l}\text { Hypertension; mitral } \\
\text { insufficiency }\end{array}$ & $\begin{array}{l}\text { Bacterial pneumonia, } \\
\text { fungal pneumonia }\end{array}$ & 15 & $\begin{array}{l}\text { arbodol, lopinavir-ritonavir, darunavir, } \\
\text { Methylprednisolone }\end{array}$ & $\begin{array}{l}\text { Severe ARDS; myocardial } \\
\text { damage }\end{array}$ \\
\hline patient 7 & 50 & $\mathrm{~F}$ & $400 \mathrm{ml}$ & None & None & 13 & $\begin{array}{l}\text { Lopinavir-ritonavir; interferon alfa, } \\
\text { Methylprednisolone }\end{array}$ & Severe ARDS \\
\hline patient 8 & 30 & $\mathrm{~F}$ & $400 \mathrm{ml}$ & None & None & 12 & $\begin{array}{l}\text { Interferon alfa, favipiravir, } \\
\text { Methylprednisolone }\end{array}$ & Severe ARDS \\
\hline patient 9 & 60 & M & $400 \mathrm{ml}$ & None & None & 12 & $\begin{array}{l}\text { Interferon alfa, favipiravir, } \\
\text { Methylprednisolone }\end{array}$ & Severe ARDS \\
\hline patient 10 & 71 & M & $500 \mathrm{ml}$ & None & None & 16 & $\begin{array}{l}\text { hydroxychloroquine, Lopinavir-ritonavir, } \\
\text { methylprednisolone }\end{array}$ & Severe ARDS \\
\hline patient 11 & 67 & $\mathrm{~F}$ & $500 \mathrm{ml}$ & hypertension & None & 15 & $\begin{array}{l}\text { hydroxychloroquine, Lopinavir-ritonavir, } \\
\text { methylprednisolone }\end{array}$ & Severe ARDS \\
\hline patient 12 & 45 & M & $200 \mathrm{ml}$ & Hypertension & None & 2 & Arbidol, Ribavirin & Severe ARDS \\
\hline patient 13 & 34 & $\mathrm{~F}$ & $200 \mathrm{ml}$ & None & None & 3 & Arbidol & \\
\hline patient 14 & 42 & $\mathrm{M}$ & $200 \mathrm{ml}$ & Hypertension & None & 2 & Arbidol & Severe ARDS \\
\hline patient 15 & 55 & $\mathrm{~F}$ & $200 \mathrm{ml}$ & None & None & 2 & Ribavirin & Severe ARDS \\
\hline patient 16 & 57 & M & $200 \mathrm{ml}$ & None & None & 3 & Arbidol, Remdesivir, Interferon-a & Severe ARDS \\
\hline patient 17 & 78 & $\mathrm{~F}$ & $200 \mathrm{ml}$ & None & None & 3 & Arbidol & Severe ARDS \\
\hline patient 18 & 56 & $\mathrm{M}$ & $200 \mathrm{ml}$ & None & None & 3 & Arbidol & None \\
\hline patient 19 & 67 & M & $200 \mathrm{ml}$ & $\begin{array}{c}\text { Cardiovascular, } \\
\text { cerebrovascular diseases }\end{array}$ & None & 3 & Arbidol, Ribavirin & None \\
\hline patient 20 & 49 & $\mathrm{~F}$ & $200 \mathrm{ml}$ & None & None & 3 & Arbidol, Oseltamivir, Peramivir & Severe ARDS \\
\hline patient 21 & 50 & M & $200 \mathrm{ml}$ & Hypertension & None & 6 & Arbidol, Interferon-a & Severe ARDS \\
\hline
\end{tabular}

there was significant rate of recovery between patients with comorbidity and patients without co-morbidity. Patients without co-existing chronic diseases infected by COVID-19 relatively recovered earlier than those who have co-existing disease after convalescent therapy. They test negative for COVID-19 PCR test after an average of 7.6 days. The average date of recovery of patients with co-existing chronic diseases infected by COVID-19 after convalescent plasma therapy was about 12 days. On the other hand patients with COVID-19 infection and who have both co-existing chronic diseases and co-infection relatively have prolonged time of recovery or require relatively long time to test negative for COVID-19 PCR test (Table 1).

\section{Reduction of pulmonary lesions on chest $\mathrm{X}$ ray exami- nations}

According to chest CTs, all patients showed different degrees of absorption of pulmonary lesions after convalescent plasma transfusion. With average range of 1-10 days after convalescent plasma therapy, a chest X-ray revealed further resolution of lung infiltrates which is from partial to persistent absorption

of consolidation or absorption of interstitial pneumonia was observed.

\section{Major anti-viral agents used for treatment of COVID-19}

Most frequently used antiviral agents were Arbodol $62 \%$ $(13 / 21)$, Lopinavir-ritonavir $43 \% \quad(9 / 21)$, and Interferon alpha $43 \%$ (9/21) and the other antiviral drugs used were: Oseltamivir, Ribavirin, Favipiravir, Hydroxychloroquine, Remdesivir and Peramivir. In more than $76 \%(16 / 21)$ patients antiviral agents were discontinued due to gradual recovery of patients after convalescent plasma transfusion. The other treatment given for the patients was anti-inflammatory drug Methylprednisolone $71 \%(15 / 21)$

\section{Convalescent plasma adverse effects}

None of the studies analyzed in this systematic review reported serious adverse events. During convalescent plasma transfusion to severely ill COVID-19 patients, no serious adverse effects were reported. Only one patient (1/21) showed minor facial red spot. 


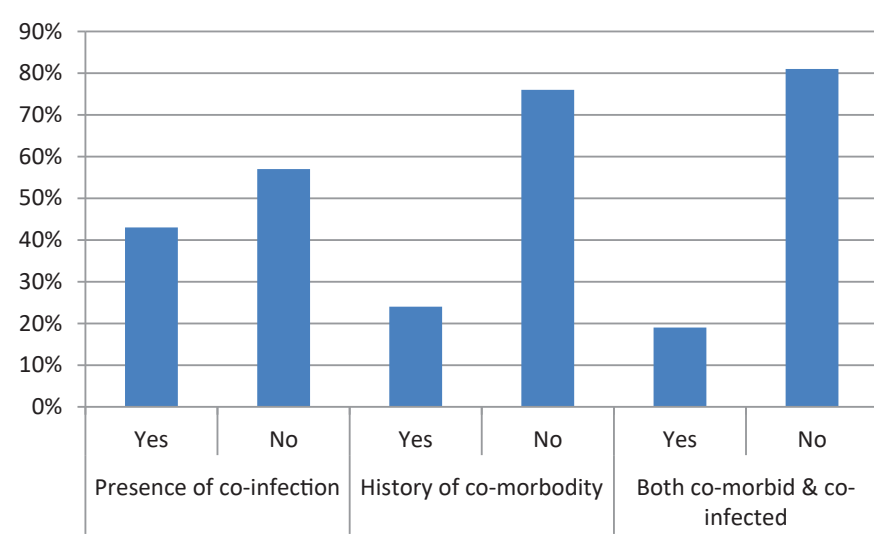

Figure 1: Presence of comorbidity and co-infection in patient with COVID-19.

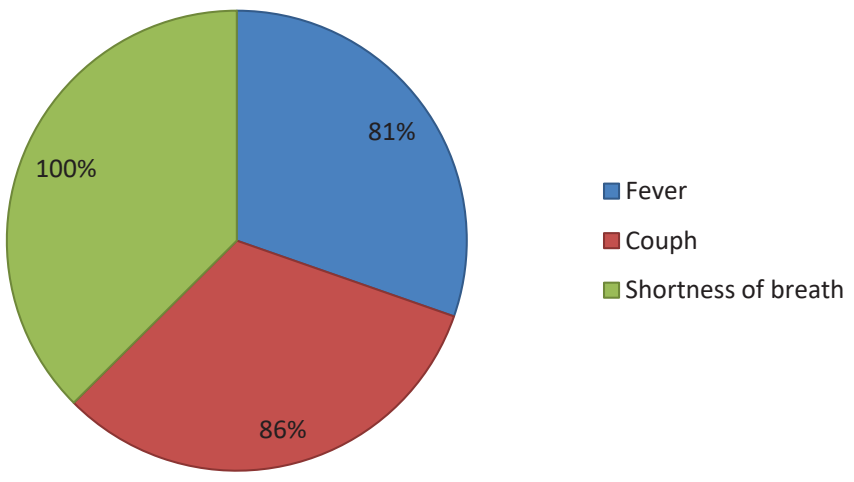

Figure 2: Most common clinical features for admission of COVID-19.

\section{Discussion}

The therapeutic benefits of convalescent plasma transfusion for infectious diseases began in the 20th century. Lesson learnt from proven effectiveness of convalescent plasma as a potential treatment of MERS-CoV, SARS-CoV and H5N1 influenza in the last decades $(8,9)$, can hold true that convalescent plasma transfusion can be an important optional treatment in patients with critical clinical disease stage in the absence of specific treatment of COVID-19 infection.

In this review we have demonstrated that there was significant difference of rate of recovery between patients with co-morbidity and patients without co-morbidity. Patients without co-existing chronic diseases infected by COVID-19 relatively recovered earlier than those who have co-existing disease after convalescent therapy.

Majority of complications observed in the study participants were severe acute respiratory distress, pneumorrhagia, cystorrhagia and gastrointestinal bleeding, myocardial damage, and cardiac dysfunction. This could be reason to death in patients infected by COVID-19.

According to data this systemic review to evaluate the clinical effects of convalescent plasma therapy after evidence recovery of patients, partial to persistent absorption of consolidation within the lung, ex-tubation of mechanical ventilation within
1-3 days of CPT showed that convalescent plasma can be a promising treatment option for severe COVID-19 patients.

As a limitation there is no well-designed study conducted to see effectiveness of convalescent plasma transfusion therapy we included systematic analysis of detail case reports of patients who have received convalescent plasma transfusion therapy for COVID-19 and the clinical outcome after transfusion. The other limitation is that this study is a systematic review of case series which does not have control.

\section{Conclusions and recommendation}

This study indicated that convalescent plasma transfusion might be a potential treatment for critically ill patients infected with COVID-19 and it can be helpful to reduce the risk of mortality of critically ill patients. We demonstrated no serious adverse reactions associated with the transfusion of convalescent plasma. This review suggests that convalescent plasma from patients who have recovered from COVID-19 infection might be an option to treat patients without causing severe adverse effects. Adequately assessing safety and efficacy of convalescent plasma therapy is essential. So, this study recommends that safety and efficacy of convalescent plasma transfusion in SARS-CoV-2-infected patients should be studied using well-designed clinical trial. The good outcome observed in critically ill patients; push us to recommend well organized trial of convalescent plasma transfusion in early infection before get in to critical illness stage.

\section{Declarations}

\section{Availability of data and materials}

All the datasets generated and analyzed during the review are included in this article.

\section{Author's contribution}

E. A, K. D, A. A and F. B designed the study, extracted, critically reviewed and analyzed data and wrote the first draft of the manuscript, and approved the manuscript.

\section{References}

1. FIP health advisory. COVID-19 clinical information and treatment guideline. 2020. Link: https://bit.ly/3dlv9Sg

2. Chen N, Zhou M, Dong X, Qu J, Gong F, et al. (2020) Epidemiological and clinical characteristics of 99 cases of 2019 novel coronavirus pneumonia in Wuhan, China: A descriptive study. Lancet 395: 507-513. Link: https://bit.ly/3dCkvN2

3. Zhou P, Yang XL, Shi ZL (2020) A pneumonia outbreak associated with a new coronavirus of probable bat origin. Nature 579: 270-273. Link: https://go.nature.com/3ibQ8jZ

4. WHO (2020). World Health Organization, Coronavirus disease (COVID-19) Pandemic. Link: https://bit.ly/3eHWgyn

5. WHO (2020) Coronavirus disease 2019 (COVID-19) Situation Report. Link: https://bit.ly/3dF5f1N

6. Park WH (1932) Therapeutic use of antipoliomyelitits serum in preparalytic cases of poliomyelitis. JAMA 99: 1050-1053. Link: https://bit.ly/38ehSjl

7. Park WH, Freeman RG (1926) The prophylactic use of measles convalescent serum. JAMA 87: 556-558. Link: https://bit.ly/3ibxDwg 
8. Rambar AC (1946) Mumps; use of convalescent serum in the treatment and prophylaxis of orchitis. . Am J Dis Child 71: 1-13. Link: https://bit.ly/31q9snz

9. Luke TC, Casadevall A, Watowich SJ, Stephe H, John B, et al. (2010) Hark back: passive immunotherapy for influenza and other serious infections. Crit Care Med 38: e66-e73. Link: https://bit.ly/31q94Wj

10. Roback JD, Guarner J (2020) Convalescent Plasma to Treat COVID-19 Possibilities and Challenges. 323: 1561-1562. Link: https://bit.ly/2YHRkUy

11. Hung IF, KW To K, Lee CK, Lee CL, Chan K, et al. (2011) Convalescent plasma treatment reduced mortality in patients with severe pandemic influenza A (H1N1) 2009 virus infection. Clin Infect Dis 52: 447-456.Link: https://bit.ly/2AgKZWS

12. FDA (2020) Investigational covid-19 convalescent plasma-emergency INDs. Link: https://bit.ly/3ibwwwA.

13. Tiberghien $P$, de Lambalerie X, Morel P, Gallian P, Lacombe K, et al. (2020) Collecting and evaluating convalescent plasma for COVID-19 treatment: why and how. Link: https://bit.ly/2YEJrPO
14. Robbins JB, Schneerson R, Szu SC (1995) Perspective: hypothesis: serum IgG antibody is sufficient to confer protection against infectious diseases by inactivating the inoculum. J Infect Dis 171: 1387-1398. Link: https://bit.ly/2Vt2NFp

15. Zhang B, Liu S, Tan T, Huang W, Dong $Y$, et al. (2020) Treatment with convalescent plasma for critically ill patients with SARS-CoV-2 infection. Chest. Link: https://bit.ly/3ibOoHt

16. Shen PC, Wang PZ, Zhao PF (2020) Treatment of 5 Critically III Patients With COVID-19 With Convalescent Plasma. JAMA 323: 1582-1589. Link: https://bit.ly/38b1Zuf

17. Ahn JY, Sohn Y, Lee SH, Cho Y, Hyun JH, et al. (2020) Use of Convalescent Plasma Therapy in Two COVID-19 Patients with Acute Respiratory Distress Syndrome in Korea. J Korean Med Sci 35: e149. Link: https://bit.ly/3g8shjg

18. Duan K, Liu B, Li C, Zhang H, Yu T, et al. (2020) The feasibility of convalescent plasma therapy in severe COVID-19 patients: a pilot study. medRxiv Link: https://bit.ly/2BPn2WO

\section{Discover a bigger Impact and Visibility of your article publication with}

\section{Peertechz Publications}

\section{Highlights}

* Signatory publisher of ORCID

- Signatory Publisher of DORA (San Francisco Declaration on Research Assessment)

* Articles archived in worlds' renowned service providers such as Portico, CNKI, AGRIS, TDNet, Base (Bielefeld University Library), CrossRef, Scilit, J-Gate etc.

* Journals indexed in ICMJE, SHERPA/ROMEO, Google Scholar etc.

* OAI-PMH (Open Archives Initiative Protocol for Metadata Harvesting)

* Dedicated Editorial Board for every journal

* Accurate and rapid peer-review process

* Increased citations of published articles through promotions

* Reduced timeline for article publication

Submit your articles and experience a new surge in publication services (https://www.peertechz.com/submission).

Peertechz journals wishes everlasting success in your every endeavours.

Copyright: @ 2020 Awulachew E, et al. This is an open-access article distributed under the terms of the Creative Commons Attribution License, which permits unrestricted use, distribution, and reproduction in any medium, provided the original author and source are credited. 